\title{
Market Chain Analysis of Agro-forestry Products: The Case of Fruit at Tembaro District, Kembata Tembaro Zone South Ethiopia
}

\author{
Nega Mateows ${ }^{1, *}$, Teshale Wolde Amanuel², Zebene Asfaw ${ }^{2}$ \\ ${ }^{1}$ College of Agriculture and Natural Resources, Dilla University, Dilla, Ethiopia \\ ${ }^{2}$ Wondo Genet collage of Forestry and Natural Resources, Hawassa University, Shashemene, Ethiopia
}

Email address:

negamathe@gmail.com (N. Mathewos)

\section{To cite this article:}

Nega Mateows, Teshale Wolde Amanuel, Zebene Asfaw. Market Chain Analysis of Agro-forestry Products: The Case of Fruit at Tembaro District, Kembata Tembaro Zone South Ethiopia. International Journal of Business and Economics Research.

Vol. 4, No. 4, 2015, pp. 201-216. doi: 10.11648/j.ijber.20150404.13

\begin{abstract}
Ethiopia has a variety of fruit crops grown in different agro ecological Zones by small farmers, mainly as a source of income as well as food. The nature of the product on one hand and the lack of market system on the other hand have resulted in low producers' price and hence low benefit by the producers. This study was carried out to analyse the market chain of agroforestry products such as mango, avocado and banana. Two kebeles were selected based on the presence of fruit production. Data was collected from 140 mango, banana and avocado producing households, 7 local collectors and 13 retailers through structured interview, focus group discussion, key informant interviews, market assessment as well as field observation. Structure, Conduct and Performance (SCP) approach was used to analyze avocado, banana and mango market also OLS (Multiple linear regression model) was used to analyzed factors that determine banana, mango and avocado market supply of the producers in the area. The market actors in the survey period were producers, rural assemblers, retailers, and consumers. Banana, mango and avocado market structure in the area shows the competitive nature. Among the different variables that were hypothesized as determining factors for volume of marketable supply the econometric result showed that price, access to extension service, distance, access to market information and quantity produced for mango and avocado were significant whereas active family size, distance, quantity produced, access to market information, and price for banana were significant. For each fruit types there are four marketing channels. Among the channels the producer-retailer-consumer channel was identified as the first important marketing channel in terms of volumes of each fruits transacted while the producer-local collector-consumer channel was identified as the least marketing channel in terms of volumes of each fruits transacted. Fruit trading in the study area is considered as a low profile activity mainly handled by female traders. There is a tradition that trading fruits in the study area is not by male. So, it is strongly recommended that stockholders will give awareness creation for the society in order to minimize such kind of tradition from the society and to encourage male fruit traders in the study area.
\end{abstract}

Keywords: Agroforestry, Market Chain Analysis, Structure, Conduct and Performance

\section{Introduction}

The majority of the Ethiopian populations live in rural areas where agriculture is the main occupation and source of livelihood. It contributes for about $47.3 \%$ of GDP and $90 \%$ of export earnings (NBE, 2006).

Ethiopia is one of the developing countries with high population and food insecurity. The country has been implementing different strategies to achieve food security. Diversification of crops, increasing the availability of food production, and encouraging the production of early maturing and high yielding crops in different agro-ecologies of the country are some of such strategies (CSA, 2009). Food security is one of the most important problems for the rural population of Ethiopia, whose life is almost entirely dependent on agricultural products.

Ethiopia is characterized by having different agroecological zones and it accounts about a total area of 1.13 million $\mathrm{km}^{2}$ (Kahsay et al., 2008). A variety of fruit crops has been growing in different agro ecological Zones by small 
farmers, for subsistence and income generation. About $61,972.60$ hectares of land is under fruit crops in Ethiopia. Bananas (Musa paradisiaca) contributed about $58.11 \%$ of the fruit crop area followed by avocados (Persea americana) and mangoes (Mangifera indica) that contributed $14.42 \%$ and $14.21 \%$ of the area respectively. More than $4,793,360.64$ quintals of fruits was produced in the country. Bananas (Musa paradisiaca), Mangoes (Mangifera indica), Papayas (Carica papaya), Oranges and Avocados (Persea americana) took up $63.11 \%, 14.55 \%, 8.07 \%, 7.46 \%$ and $5.35 \%$ of the fruit production, respectively (CSA, 2012).

In the study area where the research was conducted, the estimated volume of production of avocado (Persea americana) was about 15850 quintals, banana Musa paradisiaca) was 22250 quintals and mango (Mangifera indica) was 10200 quintals from which about 12800, 21800, and 9200 quintals of avocado (Persea americana), banana (Musa paradisiaca) and mango (Mangifera indica), respectively were sold (WoAD, 2012).

Bosena Tegegne (2008) indicates that increasing the value of exports is not an end in itself and it is only a means of accelerating the rate of economic growth. If market performance is inefficient, the sustainability of the production becomes questionable and as a result a continuous supply of the commodity for the market becomes difficult. Increased production needs to be accompanied by efficient marketing system. Therefore, one means of investigating the efficiency of any product marketing system is through studying the market chain of the products.

Thus, this study was initiated to enhance understanding on market chains, actors and their functions and determinates of supply fruit for agro forestry products mainly for Avocado, Banana and Mango fruits in Tembaro woreda.

\section{Objectives}

\subsection{General Objective}

The general objective of the study was to analyze the Avocado, Banana and Mango market chain and investigate the factors that influence the supply of fruits in Tembaro Woreda.

\subsection{Specific Objectives}

The specific objectives were

- To identify the actors and their functions in the Avocado, Banana and Mango market chain

- To analyze the marketing channels for agro forestry products mainly for Avocado, Banana and Mango

- To examine determinants of supply for Avocado, Banana and Mango fruits

\section{Methodology}

Tembaro Woreda is located in Kembata Tembaro Zone, SNNPR. It is located at about $400 \mathrm{~km}$ and $180 \mathrm{~km}$ south of Addis Ababa and south west of the principal city of the region Hawassa, respectively. Tembaro district is composed of 20 administrative Kebeles and bordered by Omo River in the south, Hadero and Tunto zuria Woreda in the east, Soro Woreda in the west and Duna Woreda in north. Geographically, it is located between $32^{\circ} 98^{\prime}$ E to $34^{0} 29^{\prime} \mathrm{E}$ and $8^{0} 08^{\prime} \mathrm{N}$ to $8^{0} 9^{\prime} \mathrm{N}$. The total area of the district is about 27,917 hectares. The altitude of the Woreda ranges from 800 to 2600 m.a.s.l and the slope ranges from intermediate (3$30 \%$ ) to very steep slope (above30\%) (BoARD, 2007). The study area was encompassed two kebeles namely Bachira and Debub Ambukuna.

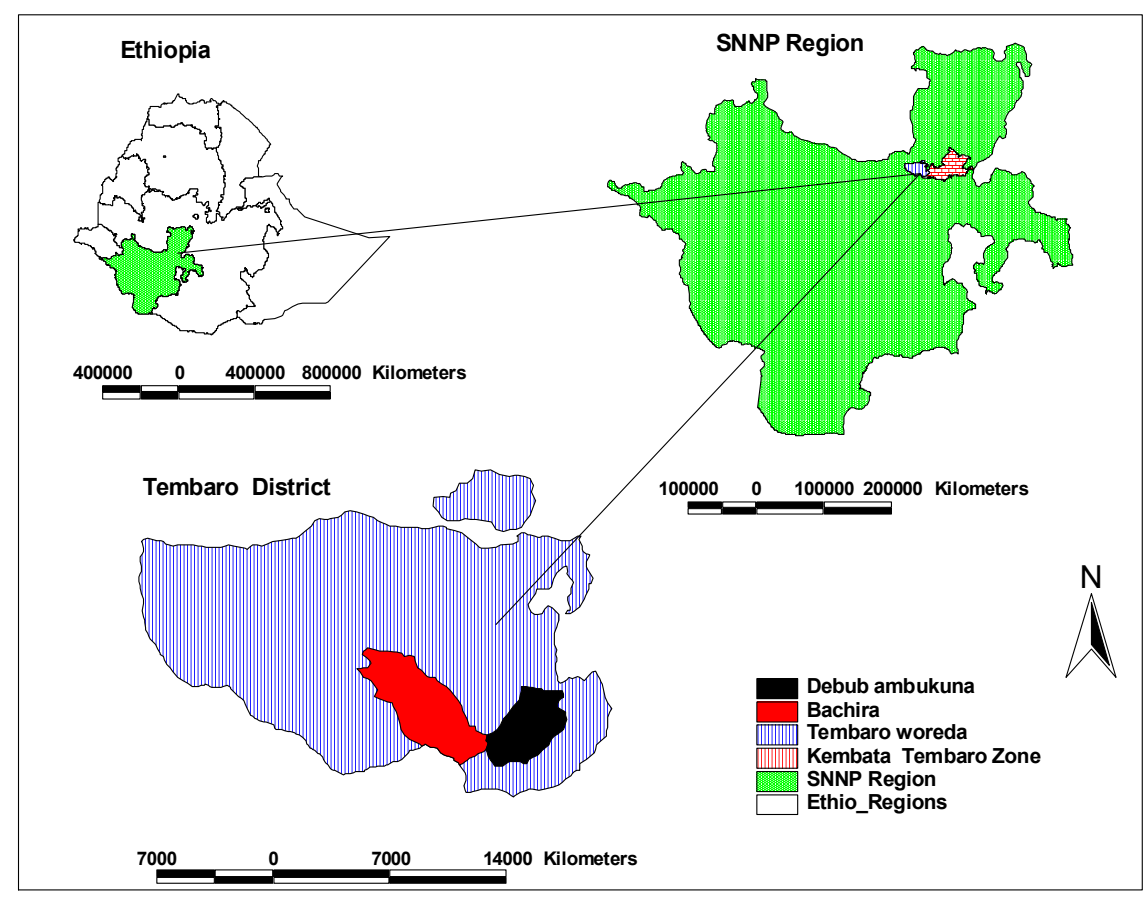

Figure 1. Map of the study area. 
Both primary and secondary sources data were employed to address the objectives of this study. The primary data was collected using two types of interview schedule (one for farmers and the other for traders). The primary data was collected from fruit producing farmers on factors affecting mango, avocado and banana market supply, quantity produced, access to market information, access to credit, access to extension service, access to market, experience of farmers on fruit production, and socioeconomic characteristics of the households. The interview schedule for traders include: types of traders (retailers, local collectors, wholesalers etc.), buying and selling strategies, source of market information and socioeconomic characteristics of the traders. Secondary data was collected from different sources, such as: government institutions, the Woreda's Agricultural Development Office, bulletins and websites.

A two-stage sampling technique was used to draw sample fruit producer farmers. First, two kebeles from the District was selected through purposive sampling approaches. During the selection, the kebele's potential for fruit production was taken into consideration. In the second stage, using the population list of fruit producer farmers from sampled kebeles, the intended sample size was determined proportionally to population size of fruit producer farmers using random sampling method. Accordingly, in this study sample size selection was based on the rule of thumb $\mathrm{N} \geq 50+8 \mathrm{~m}$, where, $\mathrm{N}$, is sample size and ' $\mathrm{m}$ ' is the number of explanatory variables $(\mathrm{Xi})$ where $\mathrm{i}=1,2 \ldots 11$. Based on this rule the researcher had taken a total sample of 140 respondents from the selected kebeles of Tembaro district. A total of 13 sample retailers and 7 local collectors were selected randomly.

\subsection{Focused Group Selection}

For focus group discussions, individuals who had experience in fruit production were selected to discuss specific issues related to the purpose of the study by forming small groups with a homogenous composition. Thus, two focus group discussions, one woman and other men consisting six persons in a group, were held in each Kebele. The reason for categorizing the discussion by sex was that women had their own interest in fruits so that they could speak more freely on certain topics like the role they play in managing the fruits and the contribution of the fruits in meeting women's financial requirements. The discussion was facilitated by the researcher together with the enumerators so group members were encouraged to talk freely on a certain topics.

\subsection{Key Informant Selection}

Individuals who had lived in the area for a long time, active and knowledgeable of their localities were selected by adapting the snow-ball ${ }^{1}$ method. Accordingly, six key

1 Snow-ball is a method of selecting key informants based on individuals (happen informants were selected from each kebele administration and a one-to-one interview was conducted with the selected key informants.

\subsection{Household Survey}

Structured questionnaires were prepared for the household survey based on the information elicited through key informant interviews and focus group discussions. The data upon which this study based was collected through a structured questionnaire administered by face to face meetings with the household head. The survey was conducted from November to December 2012. One enumerator from each kebele was selected. The enumerators have college graduates and working as development agent in the Kebeles. They were familiar with the study Kebeles. They spoken the local language and knew local customs and traditions. Their role was to convince farmers to voluntarily respond without hesitation and gave actual information during the interview. The role of the researcher was facilitation and supervision.

\subsection{Method of Data Analysis}

For data analysis, both descriptive statistics and econometric analyses were employed. The descriptive statistics like mean, min, max, standard deviation, percentages and frequencies were used to examine and understand the socioeconomic characteristics of the respondents as well as the structure, conduct and performance of fruit market. The data was analyzed by using Statistical Package for Social Science (SPSS) version 20 and Excel 2007.

The econometric analysis was used to estimate the factors that affect the supply of avocado fruits. Multiple linear regression model was used since there are more than one independent variables. Here the estimated coefficients indicate the effect of a change in the independent variables on the dependent variable.

Since the dependent variable, the supply of fruit is a continuous variable, OLS model was used and the OLS regression is specified as:

$$
Y_{i}=\alpha_{i}+\beta_{1} X_{1}+\beta_{2} X_{2}+\beta_{3} X_{3}+\ldots \ldots \ldots \ldots . . .+\beta_{i} X_{i}+U_{i}
$$

Where: $Y_{\mathrm{i}}=$ quantity of avocado supplied to market $\alpha_{\mathrm{i}}=$ Intercept

$\beta_{\mathrm{i}}=$ Coefficient of the $\mathrm{i}^{\text {th }}$ explanatory/independent variable

$\mathrm{X}_{\mathrm{i}}=$ Vector of explanatory variables

$\mathrm{U}_{\mathrm{i}}=$ disturbance term

Hence, the equation for the quantity of avocado supplied is: Quantity of Avocado Supplied $=\alpha_{i}+\beta_{1}$ Sex $+\beta_{2}$ Age + $\beta_{3}$ Family size $+\beta_{4}$ Edu $+\beta_{5}$ Distance $+\beta_{6}$ Experience + $\beta_{7}$ Quantity produced $+\beta_{8}$ Price $+\beta_{9}$ Extension $+\beta_{10}$ Market Information $+\beta 11$ credit $+\mathrm{U}_{\mathrm{i}}$

Before estimating the parameters multicolliniarity and heteroscedasticity detection tests were performed using

to meet by chance) suggestion. 
appropriate test statistics. Variance Inflation Factor (VIF) and Contingency coefficient (CC) were employed to test the existence of multicolliniarity problem among continuous explanatory variables and dummy variables respectively. The result shows that all of the VIF values were less than 10 and thus, there was no serious multicolliniarity problem among independent continuous variables (see annex 1). The result of the contingency coefficient indicates the absence of multicolliniarity problem among the independent dummy variables (see annex 2). The presence of heteroscedasticity in this study was checked by using the Breusch-Pagan (BP) test. Hence, there was no heteroscedasticity problem in the data.

\section{Results and Discussion}

\subsection{Socio-Economic Characteristics of Fruit Producers and Traders}

Fruit producing households have diverse socioeconomic profiles in the study area. The family size profile of the respondents shows that they have large family size with an average size of 8 . There are households that have as low as two family members to those households having as large as fourteen members in the family. The age of the respondents varies between 25 to 60 years with an average age of 41.82 . With respect to educational status $40 \%$ of fruit producing household heads did not attend formal education, but $60 \%$ of the sampled household heads attended formal education though the level of education is less than grade 4 . Nevertheless, the same households have ample experience with respect to fruit production especially the traditional fruits such as banana. With respect to the non-traditional ones such as avocado and mango the households have relatively few years of experience. Notably, they have an average of 9.54 years of experience in producing avocado with minimum of 5 years and maximum of 13 years of experience. The majority of the avocado producers (85.72\%) were married and among them $78.57 \%$ of them were male while the rest $(21.43 \%)$ were female. Regarding religion, almost three fourth of the respondents $(74.29 \%)$ were Protestant and the remaining $24.28 \%$, and $1.43 \%$ were followers of Orthodox, and Catholic respectively.

With respect to the socioeconomic profile of the traders, $95 \%$ of fruit traders were females. In contrast to the age of avocado producers, the avocado traders are relatively younger than the producers. The age of the traders ranged between 16 years to 34 years with an average age of 21.7 year. Furthermore, they have few experiences with an average age of 3.45 years in avocado trading with minimum of 3 and maximum of 4 years of experience. The avocado traders have relatively better level in their educational status than the producers. That is, 90 percent of the traders attended formal education (40 percent attended elementary school, 35\% attended secondary school, and the remaining $15 \%$ attended grade $9-10$ ). However, only $10 \%$ of sampled traders did not attended formal education, regarding their religion $75 \%$ of the traders were Protestant, $25 \%$ were
Orthodox.

\subsection{Structure, Conduct, and Performance of Fruits Marketing}

\subsubsection{Market Structure}

In this subsection the nature of market structure of avocado, banana and mango were presented and discussed with respect to the types of actors and their functions in the chain, marketing channel of each fruit, the degree of market transparency, the degree of market concentration and entry and exit barriers.

a. Actors and their functions in fruit markets

The result shows a variety of actors in fruit marketing in the study area. They include producers, local collectors, retailers and final consumers of the products.

Producers: They are the first actors in the marketing chain of fruits in the study area and all of them are smallholder farmers who produce the various types of fruits and supply to the next agents. With respect to marketing of the products, fruit producers/smallholder farmers sell the fruits they produced to different buyers/traders in the market in their village or in a market at the capital of the district.

Local collectors: These are important actors in the market chain and they collect the various fruits (e.g. avocado, banana and mango) from fruit producers or farmers and they in turn sell it to retailers and consumers.

Retailers: These are also important actors in the fruit marketing channel that deliver fruits to consumers. That is, they purchase fruits either directly from producers or local collectors and deliver to consumers.

Consumers: These are the last actors in the fruit marketing chain. They are individuals or households who buy various fruits from fruit producers, local collectors and retailers for their own consumption only. As last actors in the chain they can buy the fruits from various actors in the marketing chain. That is either directly from producers or other actors in the channel as local collectors and retailers.

b. Marketing channels tensioned

In the following subsections the condition of the marketing channel for each fruit is presented and discussed. First, banana marketing channel will be presented and discussed followed by discussion on mango marketing channel. Finally, avocado marketing channel will be presented and discussed.

i. Banana marketing channel

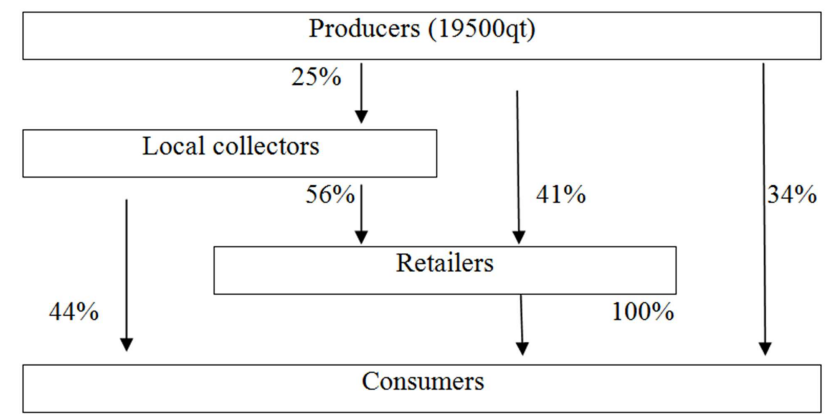

Figure 2. Marketing channel of banana. 
During the survey, four marketing channels were identified for banana and here comparison was made among channel based on the volume of the banana that passed through each channel. As indicated in figure 2, the buyers who buy the banana fruits from the producers were local collectors, consumers, and retailers and share an estimated percentage of 25, 34 and 41 respectively. Accordingly, the producer-retailer-consumer market channel shared the largest volume (i.e. $7995 \mathrm{qt}$ ) of banana fruits which is $41 \%$ of the total volume followed by producer-consumer channel which shared a total volume of $6630 \mathrm{qt}$ of banana fruits and is about $34 \%$ of the total volume. Whereas the producerlocal collector-consumer channel has the least share (11\%) this is about $2145 \mathrm{qt}$ of the banana fruits transacted in the channel.

Producer-consumer channel: This is a channel where the producers sell the banana fruits directly to final users (consumers). The channel accounted for about 34\% of the total banana marketed during the survey period. That is about 6630qt of banana is transacted via this channel and this channel found to be the second most important channel in terms of volume of banana marketed.

Producer-retailer-consumer channel: In this channel producers sell the banana fruits to retailers and the retailers in turn sell the banana fruits to consumers. It is a channel that accounted for about $41 \%$ (7995qt) of the total banana marketed. Thus, the channel was identified as the first important banana marketing channel in terms of volume of banana fruits transacted in the study area. This is in line with Adugna (2009) who explained the producer-retailerconsumer channel represents the largest volume of fruits in terms of transaction.

Producer-local collector-retailer-consumer channel: In this channel the consumers purchase the banana fruits from retailers via local collectors. This channel accounts for about $14 \%(2730 \mathrm{qt})$ of the total banana fruits marketed during the survey period.

Producer-local collector-consumer channel: In this channel the consumers buy the banana fruits from producers via local collectors and the channel accounts for about $11 \%(2145 \mathrm{qt})$ of the total volume of banana fruits transacted during the survey period. The least share of the channel from the total volume of the banana fruits might be because local collectors sell more of the fruits to retailers rather than selling to consumers based up on prior agreement made between them. The result coincides with the findings of Adugna (2009) who stated that producerlocal collector-consumer channel represented the least share in terms of the volume of the fruits which passed through the channel.

ii. Mango market channel

Four marketing channels were identified in the study area with respect to mango fruits. These are producer-consumer channel, producer-retailer-consumer channel, producerlocal collector-retailer-consumer channel and producerlocal collector-consumer channel. The result shows that among the channels the producer-retailer-consumer channel accounts the largest volume $(45 \%)$ of the mango fruit marketed followed by the producer-consumer channel which accounts for $30 \%$ of the total mango fruits marketed in the channel.

Producer-consumer channel: In this channel producers sell mango fruits directly to the consumers. The channel accounts for $30 \%$ (2760qt) of total mango marketed in the study area during the survey period. The channel was found to be the second important channel in terms of volume of mango fruits transacted.

Producer-retailer-consumer channel: In this channel the producers sell mango fruits to retailers and the retailers in turn sell the mango fruits to consumers. The channel represents $45 \%$ (4140qt) of the total mango marketed during the survey period. The channel was identified to be the first important mango fruit marketing channel in the study area in terms of volume of mango fruits marketed. This might be because local collectors in the area are part time traders so they may not buy as much as mango fruits as retailers. Therefore, retailers can buy more quantity of mango fruits than local collectors. This makes the transaction of mango fruits in producer-retailer-consumer channel to be the highest. This is in line with Woldemicheal (2008) who explained the producer-retailer-consumer channel represents the largest volume of in terms of sell.

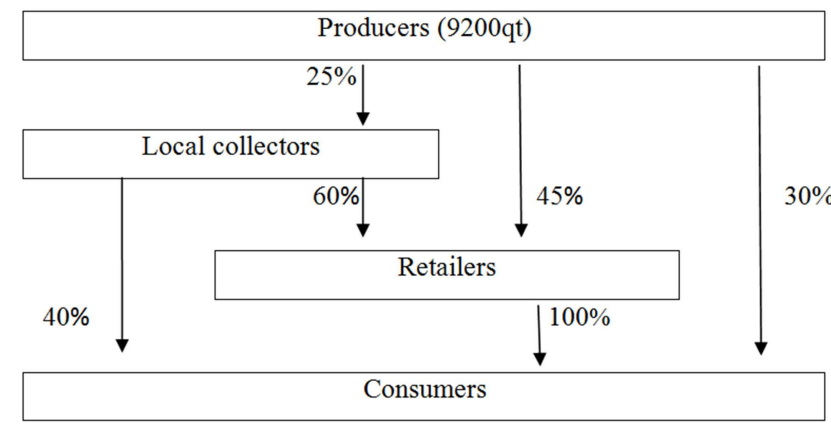

Figure 3. Marketing channel of mango.

Producer-local collector-retailer-consumer channel: In this channel the consumers purchase the mango fruits from retailers via local collectors. The channel accounted for $15 \%$ of total mango fruits marketed (1380qt) during the survey period.

Producer-local collectors-consumer channel: This channel accounts for about $10 \%$ (920qt) of total mango marketed during the survey period. This channel was found to be the least in terms of volume of mango fruits transacted. This might be because local collectors sell more of the fruits to retailers rather than selling to consumers. The reason is the prior agreement they make with retailers and the workload is also low when they sell to the retailers than directly to consumers. The result coincides with the findings of Adugna (2009) who stated that producer-local collector-consumer channel represented the least share in terms of fruits which passed through the channel.

iii. Avocado market channel

Similar to banana and mango marketing channels four 
marketing channel were also identified for avocado and comparison was made among channels based on the volume of avocado fruits that were transacted through the channel. Accordingly, the producer-retailer-consumer market channel shared the largest volume (i.e. 5248qt) of avocado fruits which is $41 \%$ of the total volume of avocado fruits transacted followed by producer-consumer channel which shared $31 \%$ (3968qt) of the total volume of avocado fruits transacted.

Producer-consumer channel: In this channel producers sell avocado fruits directly to the consumers. The channel accounts for about $31 \%$ (i.e. $3968 \mathrm{qt}$ ) of avocado which was transacted during the survey period and it stands second in terms of the volume of avocado transacted in the market.

Producer-retailer-consumer channel: In this channel producers sell avocado fruits to the retailers and the retailers in turn sell the fruits to consumers. The channel accounts for $41 \%$ (5248qt) of the total avocado transacted during the survey period and it stand first in terms of the volume of avocado fruits exchanged.

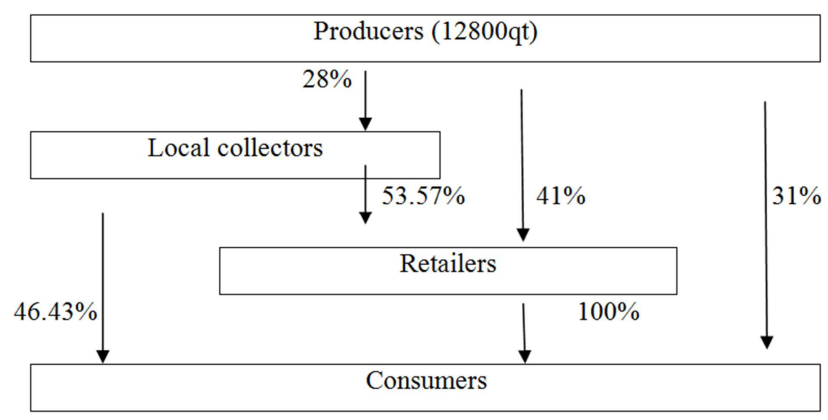

Figure 4. Marketing channel of avocado.

Producer-local collector-retailer-consumer: in this channel the consumers purchase the avocado fruits from retailers via local collectors. The channel accounts for about $15 \%$ (1920qt) of avocado fruits which was marketed during the survey period.

Producer-local collector-consumer: in this channel the consumers buy the avocado fruits from producers via local collectors and it accounts for 13\% (1664qt) of total avocado marketed in the study area during the survey period. The channel stands last in terms of the volume of avocado fruits marketed.

In general, the result shows that there are four marketing channels for each fruits and among the channels the producer-retailer-consumer channel was identified to be the first important marketing channel in the study area with respect to the volume of each fruits transacted. This might be because in the study area local collectors are part time traders so they may not buy as much as fruits as retailers. Therefore, retailers can buy more quantity of fruits than local collectors. This makes the transaction of fruits in producer-retailer-consumer channel to be the highest. Producer-local collector-consumer marketing channel stands last for all fruits in the study area. This might be because local collectors sell more of the fruits to retailers rather than selling to consumers. The reason is the prior agreement they make with retailers and the workload is also low when they sell to the retailers than directly to consumers. This is in line with the results by Woldemicheal (2008) and Adugna (2009) who stated that the producerretailer-consumer channel was the first most important channel in terms of the volume of commodities marketed while producer-local collector-consumer marketing channel was the least marketing channel. On the other hand, from the total quantity of all fruits which was handled by local collectors, consumers purchased more quantity of avocado compared to banana and mango. This might be because most consumers consume more avocados together with bread in small cafeterias, around school and in their house. Therefore, this makes the transaction of avocado fruits between local collectors and consumers to be the highest compared to banana and mango fruits which is transacted between local collectors and consumers.

a. Degree of market transparency

The survey result indicated that only 35 percent of producers have adequate, timely and reliable market information in the study area but the remaining $65 \%$ of the fruit producers lack adequate, timely and reliable market information in the study area. This might be because poor infrastructural facilities and other related problems. With respect to traders, $55 \%$ of the traders mentioned that they have adequate, timely and reliable market information in the study area, but the remaining $45 \%$ of the traders have no adequate, timely and reliable market information in the study area. The result found out that traders have better exposure to information than the producers. This may be because the traders have better access to mobile phones and other means of getting market information. This is in line with the study of Ayelech (2011) who reported that the traders have more privileged in information access than producers.

b. Degree of market concentration

Concentration ratio is expressed in terms of CRx which stands for the percentage of the market sector controlled by the biggest $\mathrm{X}$ firms. Four firms $\left(\mathrm{CR}_{4}\right)$ concentration ratio is the most typical concentration ratio for judging the market structure. $\mathrm{A} \mathrm{CR}_{4}$ of over $50 \%$ is generally considered a tight oligopoly; $\mathrm{CR}_{4}$ between $25 \%$ and $50 \%$ is generally considered a lose oligopoly, and a $\mathrm{CR}_{4}$ of fewer than $25 \%$ is competitive

In this subsection the market concentration ratio of avocado, mango and banana traders will be presented. First, the market concentration ratio for avocado will be presented and discussed followed by the market concentration ratio for banana. Finally, the market concentration ratio for mango will be presented and discussed.

i. Concentration ratio for avocado

Concentration ratio for avocado market was calculated by taking the annually purchased volume of avocado by market participants in quintal. The degree of market concentration was measured using the common measures of market concentration that is Concentration Ratio $\left(\mathrm{CR}_{4}\right)$. 
Table 1. Concentration ratio of avocado market in Tembaro Woreda.

\begin{tabular}{|c|c|c|c|c|c|c|c|}
\hline $\begin{array}{l}\text { Number of } \\
\text { traders (A) }\end{array}$ & $\begin{array}{l}\text { Cumulative } \\
\text { frequency of } \\
\text { traders (B) }\end{array}$ & $\begin{array}{l}\begin{array}{l}\% \text { of } \\
\text { traders }\end{array} \\
\left(\mathrm{C}=\frac{A}{20}\right)\end{array}$ & $\begin{array}{l}\text { Cumulative \% } \\
\text { of traders (D) }\end{array}$ & $\begin{array}{l}\text { Quantity } \\
\text { purchased in } \\
\text { kg (E) } \\
\end{array}$ & $\begin{array}{l}\text { Total quantity } \\
\text { purchased in } \mathrm{kg} \\
\mathbf{F}=\mathbf{A} * \mathbf{E}\end{array}$ & $\begin{array}{l}\text { \% share of } \\
\text { purchase } \\
\left(\mathrm{Si}=\frac{F}{8195}\right)\end{array}$ & $\begin{array}{l}\text { \% cumulative } \\
\text { purchase } \\
\left(\mathrm{C}=\sum_{i=1}^{r} S i\right)\end{array}$ \\
\hline 1 & 1 & 5 & 5 & 600 & 600 & 7.32 & 7.32 \\
\hline 1 & 2 & 5 & 10 & 500 & 500 & 6.10 & 13.42 \\
\hline 2 & 4 & 10 & 20 & 450 & 900 & 10.98 & 24.4 \\
\hline 1 & 5 & 5 & 25 & 425 & 425 & 5.19 & 29.59 \\
\hline 3 & 8 & 15 & 40 & 420 & 1260 & 14.64 & 44.23 \\
\hline 1 & 9 & 5 & 45 & 410 & 410 & 5.00 & 49.23 \\
\hline 1 & 10 & 5 & 50 & 400 & 400 & 4.88 & 54.11 \\
\hline 6 & 16 & 30 & 80 & 380 & 2280 & 27.82 & 81.93 \\
\hline 2 & 18 & 10 & 90 & 360 & 720 & 8.79 & 90.72 \\
\hline \multirow[t]{2}{*}{2} & 20 & 10 & 100 & 350 & 700 & 8.54 & 99.26 \\
\hline & & 100 & & & 8195 & 100 & \\
\hline
\end{tabular}

Source: own computation (2012)

The result in table 1 shows that the concentration ratio for avocado is $24.4 \%$. This indicates that avocado fruit markets in the districts were characterized by unconcentrated suppliers/traders/sellers. Following the market structure criteria suggested by Kohls and Uhl (2002) avocado market showed competitive nature that was $\mathrm{CR}_{4}$ of $24.4 \%$. The result does not coincide by Assefa (2009) who found out that the oligopolistic nature of the market due to limited number of traders.

ii. Concentration ratio for banana

The market concentration ratio for banana market was calculated by taking the annually purchased volume of banana by market participants in quintal.

Table 2. Concentration ratio of banana market in Tembaro Woreda.

\begin{tabular}{|c|c|c|c|c|c|c|c|}
\hline $\begin{array}{l}\text { Number of } \\
\text { traders (A) }\end{array}$ & $\begin{array}{l}\text { Cumulative } \\
\text { frequency of } \\
\text { traders }(B) \\
\end{array}$ & $\begin{array}{l}\% \text { of } \\
\text { traders } \\
\left(\mathrm{C}=\frac{A}{20}\right)\end{array}$ & $\begin{array}{l}\text { Cumulative \% } \\
\text { of traders (D) }\end{array}$ & $\begin{array}{l}\text { Quantity } \\
\text { purchased in } \\
\text { qt }(E)\end{array}$ & $\begin{array}{l}\text { Total quantity } \\
\text { purchased in qt } \\
\mathbf{F}=\mathbf{A}^{*} \mathbf{E}\end{array}$ & $\begin{array}{l}\text { \% share of } \\
\text { purchase } \\
\left(\mathrm{Si}=\frac{F}{19724.7}\right)\end{array}$ & $\begin{array}{l}\text { \% cumulative } \\
\text { purchase } \\
\left(\mathrm{C}=\sum_{i=1}^{r} S i\right)\end{array}$ \\
\hline 1 & 1 & 5 & 5 & 1202 & 1202 & 6.1 & 6.1 \\
\hline 2 & 2 & 5 & 10 & 1150 & 2300 & 11.6 & 17.7 \\
\hline 1 & 3 & 5 & 15 & 1100 & 1100 & 5.6 & 23.3 \\
\hline 1 & 4 & 5 & 20 & 1050 & 1050 & 5.3 & 28.6 \\
\hline 4 & 8 & 20 & 40 & 1000 & 4000 & 20.3 & 48.9 \\
\hline 3 & 11 & 15 & 55 & 950 & 2850 & 14.5 & 63.4 \\
\hline 2 & 13 & 10 & 60 & 927 & 1854 & 9.4 & 72.8 \\
\hline 1 & 14 & 5 & 70 & 911 & 911 & 4.6 & 77.4 \\
\hline 3 & 17 & 15 & 85 & 900 & 2700 & 13.7 & 91.1 \\
\hline \multirow[t]{2}{*}{1} & 20 & 10 & 100 & 870 & 870 & 4.4 & 100 \\
\hline & & 100 & & & 19724 & 100 & \\
\hline
\end{tabular}

Source: own computation (2012)

The result in table 2 shows that the concentration ratio for banana is $23.3 \%$, which is less than $25 \%$. This indicates that banana markets in the districts were characterized by the prevalence of unconcentrated suppliers/traders/sellers. Therefore, this shows that the market structure of banana fruit market was competitive with $\mathrm{CR}_{4}$ of $23.3 \%$.

iii. Concentration ratio for mango
The result in table 3 shows that the market concentration for mango is $22.69 \%$. This indicates that avocado markets in the districts were characterized by the prevalence of unconcentrated suppliers/traders/sellers. Therefore, following the market structure criteria suggested by Kohls and Uhl (2002) mango market showed competitive nature with $\mathrm{CR}_{4}$ of $22.69 \%$. 
Table 3. Concentration ratio of mango market in Tembaro Woreda.

\begin{tabular}{|c|c|c|c|c|c|c|c|}
\hline $\begin{array}{l}\text { Number of } \\
\text { traders (A) }\end{array}$ & $\begin{array}{l}\text { Cumulative } \\
\text { frequency of } \\
\text { traders (B) }\end{array}$ & $\begin{array}{l}\% \text { of traders } \\
\left(\mathrm{C}=\frac{A}{20}\right)\end{array}$ & $\begin{array}{l}\text { Cumulative \% } \\
\text { of Traders (D) }\end{array}$ & $\begin{array}{l}\text { Quantity } \\
\text { purchased in } \\
\text { qt }(\mathrm{E})\end{array}$ & $\begin{array}{l}\text { Total quantity } \\
\text { purchased in qt } \\
F=A^{*} E\end{array}$ & $\begin{array}{l}\text { \% share of } \\
\text { purchase } \\
\left(\mathrm{Si}=\frac{F}{8178}\right)\end{array}$ & $\begin{array}{l}\text { \% cumulative } \\
\text { purchase } \\
\left(\mathrm{C}=\sum_{i=1}^{r} S i\right)\end{array}$ \\
\hline 1 & 1 & 5 & 5 & 500 & 500 & 6.1 & 6.1 \\
\hline 1 & 2 & 5 & 10 & 476 & 476 & 5.81 & 11.91 \\
\hline 1 & 3 & 5 & 15 & 450 & 450 & 5.51 & 17.42 \\
\hline 1 & 4 & 5 & 20 & 431 & 431 & 5.27 & 22.69 \\
\hline 2 & 6 & 10 & 30 & 420 & 841 & 10.28 & 32.97 \\
\hline 6 & 12 & 30 & 60 & 406 & 2435 & 29.8 & 66.77 \\
\hline 1 & 13 & 5 & 65 & 401 & 401 & 4.9 & 67.67 \\
\hline 1 & 14 & 5 & 70 & 388 & 388 & 4.74 & 72.41 \\
\hline 4 & 18 & 20 & 90 & 385 & 1541 & 18.84 & 91.25 \\
\hline 1 & 19 & 5 & 95 & 361 & 361 & 4.41 & 95.66 \\
\hline \multirow[t]{2}{*}{1} & 20 & 5 & 100 & 355 & 355 & 4.34 & 100 \\
\hline & & 100 & & & 8178 & & \\
\hline
\end{tabular}

Source: own computation (2012)

a. Entry and exit barriers

Regarding entry and exit, the data shows that there are no technical, financial, and institutional barriers. All the fruit producers and traders can enter in to the market without any limitations. The same is true when they want to leave the market. This means that anyone who wants to engage in fruit marketing can enter into the market without any problem. This is also ascertained by the concentration ratio results. Since the concentration ratio of all fruits shows the competitive nature of the fruit market in the area, the traders can enter into and exit from the market easily. So, there are no entry and exit barriers in fruits marketing in the study area.

\subsubsection{Market Conduct}

In this subsection conduct of both producers and traders in avocado, banana and mango market is presented and discussed in terms of price setting and terms of payment.

a. Conduct of producers

Price setting

The result in table 4 shows that $94.3 \%$ of the respondents indicated that fruit price was set by demand and supply interaction. This means that buyers and sellers negotiate in the process and finally agree to exchange the products with the agreed up on price. But only in rare cases $(5.7 \%)$ the producers set at the price. The selling strategy of the respondent farmers is open to any buyer. This is in line with Ayelech (2011) who stated that the greater proportion of price for avocado and mango was set by demand and supply interaction and the selling strategy of the respondent farmers was open to any buyer.

Table 4. Price setting according to the producers.

\begin{tabular}{lll}
\hline Who sets price in the market & Number of respondents & Percentage \\
\hline Producers & 8 & 5.7 \\
Market (demand and supply) & 132 & 94.3 \\
\hline
\end{tabular}

Source: Survey result (2012)
Terms of payment

The survey result in table 5 shows that almost all producers in the study area practiced cash in hand system. Out of the total respondents $95 \%$ of the respondents receive the price for their product as soon as they sold and the remaining 5\% receive the price other day. In rare cases due to the perishable nature of the fruits, the farmers are enforced to sell the fruits for traders or consumers, deferring the recipe of the money/cash the other day. But in most of the cases the producers in the study area practiced cash in hand system so they are not willing to take the price some days after they sold their product because they may use the money for their daily and other related problems. This is in line with the findings of Adugna (2009) who explained that large proportion of the fruit producers practiced cash in hand system and take the price as soon as they sell the fruits.

Table 5. Terms of payment.

\begin{tabular}{lll}
\hline Terms of payment & No of respondents & Percentage \\
\hline As soon as they sold the product & 133 & $95 \%$ \\
Other day & 7 & $5 \%$ \\
\hline
\end{tabular}

Survey result (2012)

\section{b. Conduct of traders}

Price setting

The result in table 6 indicates that $80 \%$ of the price was set by demand and supply interaction via the negotiation of sellers and buyers and the remaining $20 \%$ was set by the traders themselves. The result shows that majority of the price was set by demand and supply interaction of sellers and buyers and the least amount was set by the traders' themselves. The result is in line with Adugna (2009) who found out that large proportion of the price for fruits were set by negotiation with farmers and traders and the least amount was set by traders. 
Table 6. Price setting strategy of traders.

\begin{tabular}{lll}
\hline Price set by & No of traders & Percentage \\
\hline Demand and supply & 16 & $80 \%$ \\
Traders themselves & 4 & $20 \%$ \\
\hline
\end{tabular}

Source: Survey result (2012)

Terms of payment

Table 7 shows that $90 \%$ of the traders pay the price as soon as they buy the fruits and the remaining $10 \%$ pay the price on the other day. This might be due to the competitive nature of the fruit market in the study area. Therefore, to compute with their competitors the traders pay the price as soon as they buy the fruits, but in rare cases they intended to pay the price another day.

Table 7. Terms of payment.

\begin{tabular}{ll|l}
\hline Terms of payment & No of respondents & Percent \\
\hline As soon as they bought the fruits & 18 & $90 \%$ \\
Other day & 2 & $10 \%$ \\
\hline
\end{tabular}

Source: own computation (2012)

\subsection{Market Performance}

In this subsection the market performance of the three fruits in terms of the marketing margin will be presented and discussed. First, the performance of avocado will be presented followed by mango and banana respectively.

i. Market performance of Avocado

Table 8 presents the results of the marketing margin among different actors in different channels. It shows that farmer's share of the total consumer price was $100 \%$ in channel I, $85.7 \%, 82.6 \%$ and $86.4 \%$ in channel II, III and IV respectively. This implies that $14.3 \%$ of the total consumer price in channel II, $17.4 \%$ of the total consumer price in channel III and $13.6 \%$ of the total consumer price in channel IV results from marketing activities by traders. Without considering channel I (producers sell directly to consumer) the total gross marketing margin (TGMM) is the highest in channel III which is about $17.4 \%$ and lowest in channel IV which is about $13.6 \%$. Producer's share (GMMp) is highest $(86.4 \%)$ from the total consumers' price in channel IV and lowest in channel III $(82.6 \%)$. The relatively lowest share of producers in channel III is because of the involvement of local collectors in this channel. Retailers have got relatively higher marketing margin which is $8.7 \%$ whereas local collectors have got lower marketing margin which is $8.6 \%$.

Table 8. Market performance of Avocado in terms of marketing margin with respect to the share of actors in each channel.

\begin{tabular}{|c|c|c|c|c|c|}
\hline Actors & Price in birr & Channel 1 & Channel 2 & Channel 3 & Channel 4 \\
\hline \multirow{3}{*}{ Producer } & Selling price & 200 & 180 & 190 & 190 \\
\hline & Farmers share $\%$ & 100 & 85.7 & 82.6 & 86.4 \\
\hline & TGMM\% $\%$ & & 14.3 & 17.4 & 13.6 \\
\hline \multirow{4}{*}{ Local collector } & Selling price & & & 210 & 220 \\
\hline & Margin & & & 20 & 30 \\
\hline & Marketing margin\% & & & 8.6 & 13.6 \\
\hline & ТСММа\% & & & 49.4 & 100 \\
\hline \multirow{4}{*}{ Retailer } & Selling price & & 210 & 230 & \\
\hline & Margin & & 30 & 20 & \\
\hline & Marketing margin \% & & 14.3 & 8.7 & \\
\hline & TCMMr\% $\%$ & & 100 & 50.6 & \\
\hline Final consumer price & & 200 & 210 & 230 & 220 \\
\hline TCMM & & & 30 & 40 & 30 \\
\hline
\end{tabular}

Source, Survey result (2012)

\section{ii. Market performance of mango}

From table 9, the farmer's share of the total consumer price for mango fruit was $100 \%$ in channel I, $80 \%, 73.9 \%$ and $77.3 \%$ in channel II, III and IV respectively. This implies that $20 \%$ of the total consumer price in channel II, $26.1 \%$ of the total consumer price in channel III and $22.7 \%$ of the total consumer price in channel IV results from marketing activities by traders. Without considering channel I (producers sell directly to consumer) the total gross marketing margin (TGMM) is the highest in channel III which is about $26.1 \%$ and lowest $20 \%$ in channel II. Producer's share (GMMp) is highest $(80 \%)$ from the total consumers' price in channel II and lowest in channel III $(73.9 \%)$ because of the involvement of rural assemblers in this channel. Retailers have got higher marketing margin which is $15.2 \%$ whereas local collectors have got lower marketing margin which is $10.9 \%$. 
Table 9. Market performance of Mango in terms of marketing margin with respect to the share of actors in each channel.

\begin{tabular}{|c|c|c|c|c|c|}
\hline Actors & Price in birr & Channel 1 & Channel 2 & Channel 3 & Channel 4 \\
\hline \multirow{3}{*}{ Producer } & Selling price & 180 & 160 & 170 & 170 \\
\hline & Farmers share $\%$ & 100 & 80 & 73.9 & 77.3 \\
\hline & TGMM\% & & 20 & 26.1 & 22.7 \\
\hline \multirow{4}{*}{ Local collector } & Selling price & & & 195 & 220 \\
\hline & Margin & & & 25 & 50 \\
\hline & Marketing margin $\%$ & & & 10.9 & 22.7 \\
\hline & ТCMМа\% & & & 41.8 & 100 \\
\hline \multirow{4}{*}{ Retailer } & Selling price & & 200 & 230 & \\
\hline & Margin & & 40 & 35 & \\
\hline & Marketing margin $\%$ & & 20 & 15.2 & \\
\hline & TCMMr\% & & 100 & 58.2 & \\
\hline Final consumer price & & 180 & 200 & 230 & 220 \\
\hline TCMM & & & 40 & 60 & 50 \\
\hline
\end{tabular}

Source, Survey result (2012)

iii. Market performance of banana

From table 10, the farmer's share of the total consumer price for banana fruit was $100 \%$ in channel I, $66.7 \%, 64.8 \%$ and $76.1 \%$ in channel II, III and IV respectively. This implies that $33.3 \%$ of the total consumer price in channel II, $35.2 \%$ of the total consumer price in channel III and $23.9 \%$ of the total consumer price in channel IV results from marketing activities by traders. Without considering channel I (producers sell directly to consumer) the total gross marketing margin (TGMM) is the highest in channel III which is about $35.2 \%$ and lowest $23.9 \%$ in channel IV. Retailers have got the highest marketing margin which is about $20.4 \%$ whereas rural assemblers have got the lowest marketing margin which is about $14.8 \%$. Producer's share (GMMp) is highest (76.1\%) from the total consumers' price in channel IV and lowest in channel III (64.8\%).

Table 10. Market performance of Banana in terms of marketing margin with respect to the share of actors in each channel.

\begin{tabular}{|c|c|c|c|c|c|}
\hline Actors & Price in birr & Channel 1 & Channel 2 & Channel 3 & Channel 4 \\
\hline \multirow{3}{*}{ Producer } & Selling price & 40 & 30 & 35 & 35 \\
\hline & Farmers share $\%$ & 100 & 66.7 & 64.8 & 76.1 \\
\hline & TGMM \% & & 33.3 & 35.2 & 23.9 \\
\hline \multirow{4}{*}{ Local collector } & Selling price & & & 43 & 46 \\
\hline & Margin & & & 8 & 11 \\
\hline & Marketing margin $\%$ & & & 14.8 & 23.9 \\
\hline & TCMMa $\%$ & & & 42 & 100 \\
\hline \multirow{4}{*}{ Retailer } & Selling price & & 45 & 54 & \\
\hline & Margin & & 15 & 11 & \\
\hline & Marketing margin $\%$ & & 33.3 & 20.4 & \\
\hline & TCMMr\% $\%$ & & 100 & 58 & \\
\hline \multirow{2}{*}{$\begin{array}{l}\text { Final consumer price } \\
\text { TCMM }\end{array}$} & & 40 & 45 & 54 & 46 \\
\hline & & & 15 & 25 & 11 \\
\hline
\end{tabular}

Source, Survey result (2012)

\subsection{Determinants of the Supply of Fruits in the Study Area}

In this section the factors that influence the supply of the banana, mango and avocado fruits are presented and discussed. Various variables were expected to influence the volume of marketed supply of fruits which includes age of households, sex of households, active labour force, distance from the market, access to market information, access to extension service, quantity of fruits produced, price of fruits, experience, access to credit service and education level of household head. Multiple linear regression models were employed to analyze the factors that affect the supply of fruits. Before estimating the parameters multicolliniarity and heteroscedasticity detection tests were performed using appropriate test statistics.

\subsubsection{Determinants of the Supply of Mango Fruit}

In this subsection the determinants of the supply of mango fruit were presented and discussed. The econometric result in table 11 shows among the eleven hypothesized determinants of market supply of mango five variables were found significant. These were quantity of mango produced, price of mango, access to market information, access to extension service and distance from the market. The coefficient of multiple determinations $\left(\mathrm{R}^{2}\right)$ was estimated 0.876 and adjusted $\mathrm{R}^{2}$ value was 0.846 . This means that $87.6 \%$ of the variation in the dependent variable is explained by the explanatory variables included in the model. Furthermore, 
the adjusted $\mathrm{R}^{2}$ of $84.6 \%$ which is significant has further econometrics significance and reliability. consolidated the goodness of the model, hence, its

Table 11. Determinants of quantity of mango supplied to the market.

\begin{tabular}{lllll}
\hline Variables & Coefficients & Std. Err. & t & P-value \\
\hline Constant) & -0.267 & 0.981 & -0.273 & 0.786 \\
Sex of hh & 0.100 & 0.185 & 0.543 & 0.589 \\
Age of hh (in years) & 0.001 & 0.009 & 0.098 & 0.923 \\
Education level of hh & 0.011 & 0.078 & 0.134 & 0.893 \\
Quantity produced in quintal & $0.732^{* * *}$ & 0.024 & 30.825 & 000 \\
Price of mango & $0.003^{*}$ & 0.002 & 1.756 & 0.084 \\
Active family size & 0.054 & 0.042 & 1.286 & 0.203 \\
Years of experience & 0.002 & 0.027 & 0.091 & 0.928 \\
Access to market information & $0.125^{*}$ & 0.069 & 1.81 & 0.073 \\
Access to extension service & $0.522^{* *}$ & 0.199 & 2.620 & 0.011 \\
Distance from the market & $-0.170^{* * *}$ & 0.060 & -2.820 & 0.006 \\
Access to credit service & 0.033 & 0.186 & .178 & 0.895 \\
$\mathrm{R}^{2} 0.876$ & & & & \\
Adjusted $\mathrm{R}^{2} 0.846$ & & & \\
\hline
\end{tabular}

$*, * *, * * *$ indicates significance at $10 \%, 5 \%$ and $1 \%$ respectively.

Quantity of mango produced: The result in table 11 shows that the quantity of mango is significantly and positively related to marketed supply of mango at $1 \%$ significance level. The value of the coefficient for production of mango implies that an increase in production of mango by one unit per hectare resulted in an increase in farm level marketable supply of mango by 0.732 quintals, ceteris paribus. This might be because as the production of mango increases, the farmers are going to supply more quantity of mango to the market. The result coincides with Wolday (1994) and Rehima (2007) who identified an increase in agricultural products influenced market supply of the commodities positively and significantly.

Price of mango: The result in table 11 shows that the price of mango is significantly and positively related to marketed supply of mango at $10 \%$ significance level. As the price of mango increases by one unit the amount of mango supplied to the market increases by $0.003 \mathrm{qt}$, ceteris paribus. This might be because as the price for mango increase in the market, farmers will supply more quantity of mangos to the market to get better price for the products. The result coincides with the findings of Wolelaw (2005) who stated that as the price for products in the market increased, there will be higher supply of products.

Access to market information: As hypothesised access to market information is positively related to market supply of mango at $10 \%$ significance level. The result indicated that households who have access to market information can supply $0.125 \mathrm{qt}$ more than those who do not have access to market information, other things remaining constant. This might be because as the farmers have better access to market information, the probability of getting better price for the product will increase, which in turn increase the supply of the fruit to the market. This is in line with Mohammed (2011) who found that access to market information is related to the marketable supply of products significantly and positively.

Access to extension service: As hypothesised access to extension service affected the marketed supply of mango positively and significantly at $5 \%$ significance level. The coefficient indicates that individuals who have access to extension service can supply 0.522 qt more than those who do not have access to extension service, other things remaining constant. This might be because extension service enables the farmers to have better knowledge about how to get better production and productivity, and creates farmers ' awareness about new technologies. This is in line with the result of Yishak (2005), Rehima (2006), and Ayelech (2011) who found that access extension service is related positively and significantly with quantity of products supplied to the market

Distance from the market: The result in table 11 shows that distance from the market is significantly and negatively related with the marketed supply of mango at $1 \%$ significance level. An increase in distance by one kilometre indicates a decrease in the quantity of mango fruits supplied by $0.170 \mathrm{qt}$, other things remaining constant. As the distance from the production area to market place become further and further, the producers supply the lesser quantity of mango to the market. This is because the nature of the product (i.e. perishablility) and the costs which are related with transportation. This is in line with the findings of Bosena (2008) who explained that as the distance increased from the production area to market, quantity supplied to the market decreased.

\subsubsection{Determinants of the Supply of Banana Fruit}

In table 12 , the results of the parameter estimate of the model for the relationship between supply of banana and explanatory variables is presented and discussed. The result indicates that among the eleven hypothesized determinants of market supply of banana, five variables were found significant. These were active family size of households, distance from the market, quantity produced, price of banana and access to market information. The coefficient of multiple determinations $\left(R^{2}\right)$ was estimated 0.860 and adjusted $R^{2}$ 
value was 0.812 . This means that $86.0 \%$ of the variation in the dependent variable is explained by the explanatory variables included in the model. Furthermore, the adjusted $\mathrm{R}^{2}$ of $81.2 \%$ which is significant has further consolidated the goodness of the model; hence, it is econometric significance and reliable.

Table 12. Determinants of quantity of banana supplied to the market.

\begin{tabular}{|c|c|c|c|c|}
\hline Variables & Coefficients & Std. Err. & $\mathbf{t}$ & P-value \\
\hline (Constant) & $-2.178^{*}$ & 1.139 & -1.912 & 0.059 \\
\hline Sex of HHH & 0.066 & 0.192 & 0.345 & 0.731 \\
\hline Age of HHH (in years) & 0.012 & 0.009 & 1.296 & 0.198 \\
\hline Active family size of $\mathrm{HHH}$ & $0.081^{*}$ & 0.044 & 1.840 & 0.072 \\
\hline Education level of $\mathrm{HHH}$ & 0.100 & 0.189 & 0.503 & 0.616 \\
\hline Distance from the market & $-0.111^{*}$ & 0.065 & 1.695 & 0.094 \\
\hline Quantity produced in quintal & $0.735 * * *$ & 0.030 & 24.389 & 0.000 \\
\hline Price of banana & $0.486^{* *}$ & 0.201 & 2.421 & 0.018 \\
\hline Access to extension service & 0.005 & 0.185 & 0.025 & 0.980 \\
\hline Access to market information & $0.183 * *$ & 0.078 & 2.444 & 0.017 \\
\hline $\begin{array}{l}\text { Access to credit service } \\
\mathrm{R}^{2} 0.860\end{array}$ & 0.004 & 0.003 & 1.461 & 0.148 \\
\hline Adju. $R^{2} 0.812$ & & & & \\
\hline
\end{tabular}

$*, * *, * * *$ indicates significance at $10 \%, 5 \%$ and $1 \%$ respectively.

Active family labour: Active family labour was expected to positively affect the supply of fruits to the market. As hypothesized, this variable is positively related to marketable supply of banana. The result shows that active family labour is significantly and positively affected marketable supply of banana at $10 \%$ significance level. This implies that the increase in active family labour by one unit results the increase of quantity of banana fruit supplied to the market by 0.081 quintals, ceteris paribus. Households who has more active family labour is supposed to supply more than those who has less active labour in the study area. This might be because as the number of active family labour in the family increases, there could be a decrease in labour cost which the farmers are going to pay for hired labour to manage banana trees and other related activities. In addition to this there could be a decrease in transportation cost to supply it to the market. So, as the cost of transportation and labour costs decrease, there will be an increase in the quantity of supply of banana to the market. This is in line Bezabih and Hadera (2007) who observed that as active family labour increase the amount of fruits supplied to the market will also increase.

Distance from the market: As hypothesized, this variable is negatively related to marketable supply of banana. The result shows that distance from the market is significantly and negatively related to marketable supply of banana at $10 \%$ significance level. This negative relationship tells us the effect of other factor holding constant an increase in distance by one kilometre indicates a decrease in the quantity of banana supplied to the market by 0.111 quintals. The reason for this is that as distance from the production area to market place become further and further, the producers supply lesser quantity of banana to the market. This might be due to the nature of the product (i.e. perishablility) and the costs which are related with transportation. This is in line with the findings of Ayelech (2011) who explained that as the distance from the production area to market place become further and further, quantity of fruits supplied to the market decreased.

Quantity of banana produced: The result in table 12 shows that the quantity of banana is significantly and positively related to market supply of banana at $1 \%$ significance level. The coefficient for production of banana implies that an increase in production of banana by one unit per hectare results in an increase in marketable supply of banana by 0.735 quintals, other things remaining constant. This might be because as the production of banana increases, the farmers are going to supply more amounts to the market. The result coincides with Wolday (1994) and Adugna (2009) who found that the amount of grain and fruit production respectively produced by farming households affected marketable supply of each commodity significantly and positively.

Price of banana: The result show that price of banana is significantly and positively affects its marketed supply at $5 \%$ significance level. The coefficient of the variable also confirms that a unit price increase in the banana market directs the households to increase the supply banana fruit by 0.486 quintal, ceteris paribus. The positive and significant relationship between the variables indicates that as the price of banana at market raise, quantity supplied to the market will also raise. This might be because as the price for banana increase in the market, farmers will supply more amount of banana to the market to get better price for the product. This is consistent with the result of Wolelaw (2005) and Ayelech (2011) who explained that as the price for rice and fruit respectively increases, the supply of commodities to the market also increases.

Access to market information: As hypothesised access to market information is positively related to market supply of banana. Access to market information shows positive effect on supply of banana at $5 \%$ significance level. The result further indicates that households who have access to market information can supply 0.183 quintal more than those who do not have access to market information, ceteris paribus. This 
might be because as the farmers have better access to market information, the probability of getting better price for the product will increase, which in turn increase the supply of the fruit to the market. This is in line with Mohammed (2011) who found that access to market information is related with the marketable supply of teff and wheat significantly and positively.

\subsubsection{Determinants of the Supply of Avocado Fruit}

Table 13 pointed out the five variables that were found significant with respect to supply of avocado to the market.
These are distance from the market, quantity of avocado produced, price of avocado, access to extension service and access to market information. The coefficient of multiple determinations $\left(\mathrm{R}^{2}\right)$ was estimated 0.878 and adjusted $\mathrm{R}^{2}$ value was 0.862 . This means that $87.8 \%$ of the variation in the dependent variable is explained by the explanatory variables included in the model. Furthermore, the adjusted $\mathrm{R}^{2}$ of $86.2 \%$ which is significant has further consolidated the goodness of the model, hence, its econometrics significance and reliability.

Table 13. Determinants of quantity of avocado supplied to the market.

\begin{tabular}{|c|c|c|c|c|}
\hline Variables & Coefficients & Std. Err. & $\mathbf{t}$ & P-value \\
\hline (Constant) & 0.819 & 1.307 & 0.626 & 0.533 \\
\hline Sex of HHH & 0.025 & 0.212 & 0.120 & 0.904 \\
\hline Age of HHH (in years) & 0.001 & 0.012 & 0.098 & 0.922 \\
\hline Active family size of $\mathrm{HHH}$ & 0.034 & 0.076 & 0.451 & 0.653 \\
\hline Education level of $\mathrm{HHH}$ & 0.004 & 0.097 & 0.038 & 0.970 \\
\hline Distance from the market & $-0.116^{*}$ & 0.058 & -1.991 & 0.050 \\
\hline Years of experience & 0.012 & 0.028 & 0.445 & 0.658 \\
\hline Price of avocado & $0.528 * * *$ & 0.198 & 2.669 & 0.009 \\
\hline Access to extension service & $0.0550 * *$ & 0.225 & 2.444 & 0.016 \\
\hline Access to market information & $0.239 * *$ & 0.106 & 2.26 & 0.026 \\
\hline $\begin{array}{l}\text { Access to credit service } \\
\mathrm{R}^{2} 0.878 \\
\text { Adjusted } \mathrm{R}^{2} 0.862\end{array}$ & 0.044 & 0.238 & 0.183 & 0.855 \\
\hline
\end{tabular}

$*, * *$ and $* * *$ represents the level of significance at $10 \%, 5 \%$ and $1 \%$ respectively.

Distance from the market: As hypothesized, this variable is negatively related to marketable supply of avocado. The result shows that access to the market is significantly and negatively related to the marketed supply of avocado at $10 \%$ significance level. An increase in distance by one kilometre indicates a decrease in the quantity supplied by 0.116 quintals, other things remaining constant. As the distance from the production area to market place become further and further, farmers supply the lesser quantity of avocado to the market. This is because the nature of the product (i.e. perishablility) and the costs which are related with transportation. This is in line with the findings of Ayelech (2011) who explained that as the distance increased from the production area to market, quantity of fruits supplied to the market decreased.

Quantity of avocado produced: The result in table 13 shows that the quantity of avocado is significantly and positively related to marketed supply of avocado at $1 \%$ significance level. The value of the coefficient for production of avocado implies that an increase in production of avocado by one unit per hectare resulted in an increase in farm level marketable supply of avocado by 0.740 quintals, ceteris paribus. This could be because as the production of avocado increases, the farmers are going to supply more amounts to the market. The result coincides with Adugna (2009) who explained an increase of fruit production by farming households has increased market supply of the fruits significantly.

Price of avocado: As hypothesised the price of avocado shows positive and significant relationship between the variables and significant at $1 \%$ significance level. The coefficient of the variable also confirms that a unit increase in price of avocado market make the households to increase the supply of avocado to the market by $0.528 \mathrm{qt}$, other things remaining constant. This might be because as the price for avocado increase in the market, farmers will supply more amount of avocado to the market to get better price for the product. The result coincides with the findings of Wolelaw (2005) who stated that as the price for products in the market increases, the supply will also increase.

Extension service access: As hypothesised access to extension is related to the marketed supply of avocado positively and significantly at 5\% significance level. On average, if an avocado producer got more extension contact, the amount of avocado supplied to the market increase by $0.0550 \mathrm{qt}$ than those who do not have access to extension service, other things remaining constant. This might be because extension service enables the farmers to have better knowledge about how to get better production and creates farmers' awareness about new technologies. This is in line with the result of Yishak (2005), Rehima (2006), and Ayelech (2011) who found that if fruit producer get more extension service access, the marketable supply of each of the commodities will increase and it is related significantly and positively with the supply of products to the market.

Access to market information: As hypothesized access to market information shows positive effect on banana supply and significant at 5\% significance level. The result indicates that as access to market information increased, the amount of avocado supplied to the market increased on average by 
$0.239 \mathrm{qt}$, other things remaining constant. This might be because as the farmers have better access to market information, the probability of getting better price for the product will increase, which in turn increase the supply of the fruit to the market. This is in line with Mohammed (2011) who found that access to market information related with the marketable supply of agricultural commodities significantly and positively.

In general, quantity produced, price, access to extension service and access to market information were related positively and significantly with supply of mango and avocado fruit, but distance from the market was negatively and significantly related with supply of mango and avocado fruits. Whereas active family labour, quantity of banana produced, price of banana and access to market information were positively and significantly related with supply of banana, but distance from the market was negatively and significantly related with supply of banana. In the case of the three fruits quantity of fruits produced, access to market information and prices of fruits were related positively and significantly while distance from the market was negatively and significantly related with mango, banana and avocado. Active family labour was positively and significantly related with supply of banana, but it was not significant in the case of avocado and mango. This might be because the management activities of banana in the study area require more labour than avocado and mango.

\section{Conclusion and Recommendation}

\subsection{Conclusion}

The study was conducted at Tembaro woreda to analyze the mango, avocado and banana market chain and investigating the factors that influence the supply of fruits. The actors who are participating in production and marketing services of fruits in the study area include producer, local collectors, retailers and consumers. Four marketing channels are identified for transaction of each fruits and among the channels producer-retailer-consumer marketing channel shared the largest volume of transaction while producer-local collector-consumer marketing channel shared the least volume of each fruits in terms of transaction. Fruit trading in the study area is considered as a low profile activity and mainly handled by female traders. There is a tradition that trading fruits in the study area is not by male.

The result shows that fruit marketing in the area is characterized by having large number of buyers and sellers, free entry and exit and the majority of fruit price is set by demand and supply of the fruits in the market. The marketing structure of fruit in the study area is competitive market.

Moreover the OLS result shows that infrastructural, institutional and household factors influenced the supply of fruits in the area. Infrastructural factor such as access to market affects the supply of each fruits negatively and significantly. Institutional factors such as access to extension affect the supply of avocado and mango fruits positively and significantly. Among the household factors active family labour is positively and significantly related with the supply of banana fruit to the market. Quantity produced and prices are positively and significantly related with the supply of each fruits. Generally, the significant variables were consistence with priority expected sign.

\subsection{Recommendation}

Based on the findings of this study, the following points are recommended to improve marketing chains of banana, mango and avocado so as to enhance its production, productivity and marketing in the study area.

- Quantity of banana, mango and avocado produced is one of the determinant factors that affect volume of banana, mango and avocado supplied to the market positively and significantly. Therefore, concerned bodies should focus on increasing production and productivity of the fruits by supplying improved varieties of fruits for producers.

- Access to infrastructure is a critical issue which affects the supply of fruits negatively and significantly. Therefore, the intervention of governmental and nongovernmental organizations (NGO) is needed to improve the rural communities' infrastructure service in order to encourage the communities to exchange their agroforestry products effectively and efficiently.

- Fruit trading in the study area is considered as a low profile activity mainly handled by female traders. There is a tradition that trading fruits in the study area is not by male. So, it is recommended that stockholders will give awareness creation for the society in order to encourage male fruit traders in the study area.

\section{Acknowledgement}

We are deeply indebted to DeLPHE-BC Project for its generous financial support to carry out this research. Also our gratitude goes to the Tembaro District Marketing and Cooperative office for its provision of the necessary support for this study.

\section{References}

[1] Abonesh, T. 2005. Imperfect competition in agricultural markets: Evidence from Ethiopia. Journal of Development Economics 76 (2), 405-425.

[2] Adugna Gessesse, 2009. Analysis of Fruit and Vegetable Market Chains in Alamata: The Case of Onion, Tomato and Papaya, Southern Zone of Tigray. 114p.

[3] Assefa Abebe, 2009. Market Chain Analysis of Honey Production: In Atsbi Wemberta District, Eastern Zone of Tigray National Regional State. 101p.

[4] Ayelech Tadesse, 2011. Market Chain Analysis of Fruits in Gamma Woreda, Jimma Zone, Oromia National Regional State. $127 \mathrm{p}$. 
[5] Bezabih Emana and Hadera Gebremedhin, 2007. Constraints and Opportunities of Horticulture Production and Marketing in Eastern Ethiopia .Dry Lands Coordination Group Report No 46. Norway. 90p.

[6] BoARD, 2007. Agricultural and Rural Development Planning Section Report. People and Housing Survey Report, Central Statistics Authority, Addis Ababa, Ethiopia.

[7] Bosena Tegegne, 2008. Analysis of Cotton Marketing Chains: The case of Metema woreda, North Gondar Zone, Amhara National Regional State. 125p.

[8] Burnett, J., 2008. Core Concepts of Marketing. The Global Text Project funded by the Jacobs Foundation, Zurich, Switzerland.

[9] CIAT (Centro International de Agricultural Tropical), 2004. Increasing the Competitiveness of Market Chains of Smallholder's Producers. Manual, 3: Territorial Approach to Rural Agro Enterprise Development Project.

[10] CSA, 2007. Summary and Statistical Report of the 2007 Population and Housing Census. Federal Democratic Republic of Ethiopia Population Census Commission, Addis Ababa.

[11] CSA, 2009. Area and Production of Major Crops. Sample Enumeration Survey. Addis Ababa, Ethiopia.

[12] CSA, 2012. Area and Production of Major Crops. Sample Enumeration Survey. Addis Ababa, Ethiopia.

[13] Embaye Kidanu, 2010. Analysis of Butter Supply Chain: The Case of Atsbi Wemberta and Alamata Woredas, Tigray, Ethiopia. 151p.

[14] FAO (Food and Agricultural Organization), 2005. Market Segmentation of Major Avocado Markets, Sugar and Beverages Group Raw Materials, Tropical and Horticultural Products Service Commodities and Trade Division. Food and Agriculture Organization of the United Nations.

[15] Green, H.W., 2003. Econometric Analysis: Fourth Edition. New York University Macmillan Publishing Company. Implications for development interventions Master thesis.

[16] Gujarati, D., 2003. Essentials of Econometrics. Irwin McGraw-Hill Book Co. Singapore.

[17] Holloway, G, Charles Nicholson, c, and Delgado, c, 1999 Agro industrialization through Institutional Innovation: Transaction Costs, Cooperatives and Milk-Market Development in the Ethiopian Highlands. Mssd Discussion Paper No.35

[18] ICRAF, 1993. International Centre for Research in Agroforestry: Annual Report 1993. Nairobi, Kenya. pp208.

[19] Jeeshim and KUCC, 2002. Multicollinearity in Regression Models. This document is accessed online at: http://php.indiana.edu/ kucc625.

[20] Kahsay Berhe, Yigzaw Dessalegn, Yisehak Baredo, Worku Teka, and Azage Tegegne, 2007. Smallholder-based fruit seedling supply system for sustainable fruit production in Ethiopia: Improving Productivity and Market Success (IPMS) of Ethiopia Farmers Project, Addis Ababa, Ethiopia.

[21] Kilingo, J.K. and Kariuki, J.G., 2001. Marketing of Smallholder Produce. A Synthesis of Case Studies in the High Lands of Central Kenya.
[22] Kinde Aysheshm, 2007. Sesame Market Chain Analysis: The case of Metema Woreda, North Gondar Zone, Amhara National Regional State. 143p.

[23] Kohl, R.L. and Uhl, J.N., 2002, Marketing of Agricultural Product, 9th Edition, Prentice-Hall of India PLC, New Delhi

[24] Lawrence, D.S., 1992. Marketing and Agribusiness Development Paper No.1. Department of political Economy, University of Glasgow, Rome.

[25] Leakey, R. R.B., 2010. Should we be Growing More Trees on Farms to Enhance the Report, ISTF Sustainability of Agriculture and Increase Resilience to Climate Change? Special NEWS, USA.

[26] Lunndy, M., M.V. Gottret, W. Cifuentes, C. F. Ostertag, R. Best, D. Peters and S. Ferris, 2004. Increasing the Competitiveness of Market Chains for Small-holder Producers. Manual 3: Territorial Approach to Rural Ggro-enterprise Development. International Centre for Tropical Agriculture.Colombia.117p.

[27] Maddala, G.S., 1992. Introduction to Econometrics, 2nd ed. Macmillan publishing company, NewYork.

[28] Mehari Alebachew, 2012. Traditional Agroforestry Practices, Opportunities, Threats and Research needs in the highlands of Oromia, Central Ethiopia.Holetta Research Centre, Addis Ababa, Ethiopia.

[29] Meijer, P.W.M., 1994. The Function of Maize Market in Benin. Bert Broundjin, Benin. pp11- 32.

[30] Mendoza, G., 1995. A primer on marketing channels and margins. Prices, Products, and People: Analyzing Agricultural Markets in Developing Countries. Lynne Reinner Publishers, Boulder, London. pp 257-275.

[31] Mohammed Urgessa, 2011. Market chain analysis of teff and wheat production in Halaba special Woreda, Southern Ethiopia. 120p.

[32] Molua, E.L., 2005. The economics of tropical agroforestry systems: the case of agroforestry farms in Cameroon. Forest Policy and Economics 7: 199-211. Available online at www.sciencedirect.com.

[33] National Bank of Ethiopia (NBE), 2006. Annual Report. Addis Ababa, Ethiopia.

[34] Pender, J., Ruben, R., Jabbar, M. and Eleni Gebremedhin, 2004. Policies for Improved Land Management and Agricultural Land Management and Agricultural Market Development in the Ethiopian Highlands. Summary of Papers and Proceedings of a Workshop Held at the Ghion Hotel, Addis Ababa, Ethiopia. February 19 -20, 2004, IFPRI.

[35] Rehima Mussema, 2007. Analysis of Red Pepper Marketing: The case of Alaba and Siltie, Southern Ethiopia.

[36] Scott, G.J., 1995. Prices, Products and People: Analyzing Agricultural Markets in Developing Countries. Lynne Reinner Publishers, Boulder, London. 498p.

[37] Seifu Gebremariam, 2003. Status of Commercial Fruit Production in Ethiopia, Addis Ababa, Ethiopia.

[38] Tembaro Woreda Agriculture Development office (WoAD), 2007. Annual report 
[39] Tembaro Woreda Agriculture Development office (WoAD), 2012. Annual report

[40] Tomek, W.G. and Robinson, K.L., 1990. Agricultural product prices. $3^{\text {rd }}$ ed.Comell University Press. Ithaca and London. 360 p.

[41] Wolday Amha, 1994. Food Grain Marketing Development in Ethiopia after Reform 1990. A Case Study of Alaba Siraro. The PhD Dissertation Presented to Verlag Koster University. Berlin. 293p.

[42] Woldemicheal Somano, 2008. Dairy marketing chains analysis: the case of shashemane, Hawassa and dale district's milk shed, Southern Ethiopia
[43] Wolelaw, S., 2005. Factors Determining Supply of Rice: A Study in Fogera District of Ethiopia. M.Sc. Thesis Presented to the School of Graduate Studies of Haramaya University. $90 \mathrm{p}$.

[44] Yeshitela, T.B., and Nessel. T., 2004. Characterization and Classification of Mango Ecotypes Grown in Eastern Hararghe (Ethiopia).Sarhad Journal of Agriculture, 19(2): 179-180.

[45] Yishak Gecho, 2005. Determinants of Adoption of improved Maize Technology in Damote Gale Woreda, Wolaita, Ethiopia. 